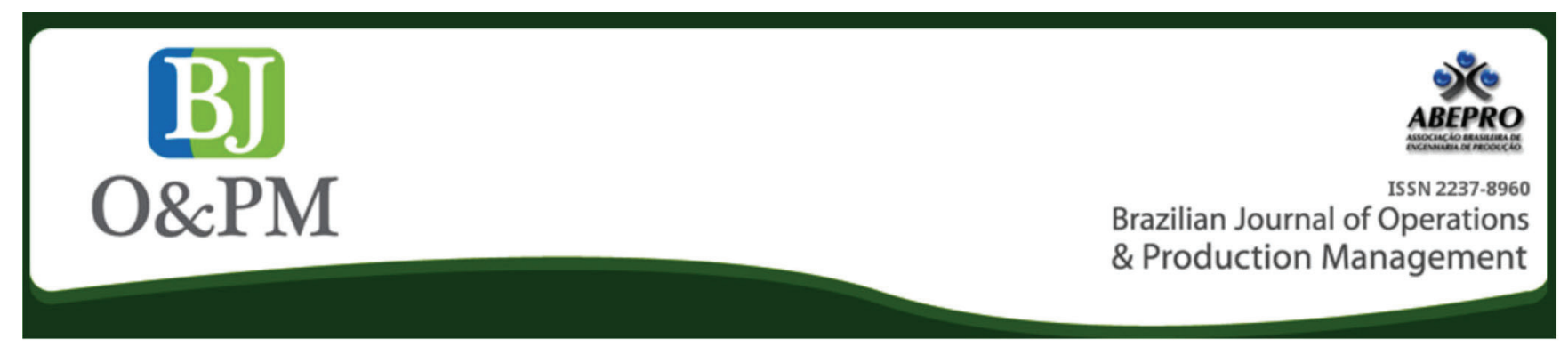

\title{
THE INTERSECTION BETWEEN BUSINESS MODEL AND MODULARITY: AN OVERVIEW OF THE LITERATURE
}

Diego Honorato Clemente diego.clemente@usp.br University of São Paulo - USP, São Paulo, São Paulo, Brazil.

\section{Juliana Hsuan}

jh.om@cbs.dk

Copenhagen Business School-

CBS, Frederiksberg, Dinamarca.

Marly Monteiro de Carvalho marlymc@usp.br

University of São Paulo - USP, São

Paulo, São Paulo, Brazil.

\begin{abstract}
Goal: To analyse the intersection between the constructs of modularity and business model in the literature.

Design/Methodology/Approach: Quantitative and Qualitative approaches were utilized through bibliometric analysis and systematic literature review. A bibliometric analysis incorporates keywords, co-citation, and country co-authorship networks generated using VosViewer Software. The research in the databases was carried out in June 2018.

Results: The intersection of modularity and business model is a rather recent study topic in the literature with a small number of articles published up to 2018. Although the concept of modularity has been widely discussed in terms of product, process and organizational levels, recent developments point to the application of this concept to services and business models.

Limitations: The main limitation refers to the sampling process that incorporated articles extracted from ISI Web of Science Core Collection only.

Practical implications: For practice, it provides companies with insights on how business model and modularity may be applied to multiple domains and can eventually contribute to firm performance and business model innovation.

Originality/Value: The originality of the article lies in providing a panorama of the literature on the intersection of business model and modularity in order to identify the main research trends.
\end{abstract}

Keywords: Business model; Modularity; Bibliometrics. 
Brazilian Journal of Operations \& Production Management

Volume 16, Número 3, 2019, pp. 387-397

DOI: 10.14488/BJOPM.2019.v16.n3.a3

\section{INTRODUCTION}

Modularity is a construct that can be related to different fields. Schilling (2000) highlights that modularity, as a general concept of systems, refers to the "degree to which the components of a system can be separated and recombined". Consequently, modularity enables the decomposition of complex tasks into simpler ones (Mikkola and Gassmann, 2003) in order to reduce the complexity of a structure (Frandsen, 2017).

Throughout the years, the concept of modularity has been applied in research to product architecture modularity, production systems modularity and organizational design modularity (Campagnolo and Camuffo, 2010), in which the concept of modularity has originally been well-discussed within the product architecture literature (Schilling, 2000; Salvador et al., 2002; Mikkola and Gassmann, 2003; Mikkola, 2006, 2007). Moreover, service modularity has been discussed recently within the literature (Pekkarinen and Ulkuniemi, 2008; Voss and Hsuan, 2009; Carlborg and Kindström, 2014; Eloranta and Turunen, 2016; Avlonitis and Hsuan, 2017; Brax et al., 2017; Frandsen, 2017; Kuula et al., 2018) and business models (Bask et al., 2010b; Bask et al., 2011; Tsvetkova and Gustafsson, 2012; Hellström, 2014; Aversa et al., 2015; Scannella, 2015; Tsvetkova et al., 2015; Gärtner and Schön, 2016; Abdelkafi et al., 2018; Snihur and Tarzijan, 2018).

Business models are broadly defined as the way firms create value to customers (Chesbrough and Rosenbloom, 2002; Baden-Fuller and Morgan, 2010; Casadesus-Masanell and Ricart, 2010; Demil and Lecocq, 2010; Teece, 2010; Zott et al., 2011), even though there has been a lack of consensus in the literature in terms of the definition of business model (Chesbrough and Rosenbloom, 2002; Teece, 2010; Zott et al. 2011). In general, the concept of business model refers to how a firm organizes itself (Baden-Fuller and Morgan, 2010; Demil and Lecocq, 2010) and how the governance of transactions is defined (Casadesus-Masanell and Ricart, 2010) to deliver value to customers and be profitable. In order to do this and be successful, business models are also related to how firms need to integrate different elements into a consistent combination (Boons et al., 2013).

In this sense, business models are seen as complex systems (Aversa et al., 2015; Foss and Saebi, 2017a, 2017b) that are based on the consideration of being architectures for value creation (Teece, 2010; Foss and Saebi, 2017a) and, as such, they are composed of interdependent building blocks or components (Casadesus-Masanell and Ricart, 2010; Demil and Lecocq, 2010; Amit and Zott, 2015). In this sense, the application of modularity principles to business models or modularization as a process itself aims to decompose them, reduce their complexity and make it manageable, as well as enhance the ability to mix, match and manipulate its ele- ments (Aversa et al., 2015; Gärtner and Schön, 2016; Foss and Saebi, 2017b).

The literature highlights many benefits harvested from modularity and business models encompassing business model innovation (Aversa et al., 2015; Bouncken et al., 2016; Gärtner and Schön, 2016; Foss and Saebi, 2017a, 2017b; Minatogawa et al., 2018), enhanced strategic flexibility (Tsvetkova and Gustafsson, 2012; Aversa et al., 2015; Tsvetkova et al., 2015; Gärtner and Schön, 2016), and cost reductions and cost-efficient operations (Bask et al., 2011b; Tsvetkova and Gustafsson, 2012; Tsvetkova et al., 2015; Abdelkafi et al., 2018), allowing customization while providing standardization of modules in service modularity (Pekkarinen and Ulkuniemi, 2008; Bask et al., 2011a; Carlborg and Kindström, 2014; Abdelkafi et al., 2018), as well as upgradability in business model building blocks for enhanced business performance/functionality (Aversa et al., 2015). On the other hand, apart from the benefits of modularity to the business model domain, the lack of fertilization between modularity and strategic concepts persists (Gärtner and Schön, 2016) as modularity has not been applied to business model literature consistently (Bask et al., 2011b), opening multiple future research possibilities (Aversa et al., 2015).

Therefore, this article aims to analyse the intersection between the constructs of modularity and business model in the literature. In order to achieve the proposed objective, the research methods incorporated both quantitative and qualitative techniques, considering bibliometrics and systematic literature review, respectively. Additionally, research gaps and themes are identified. Lastly, this article is an expanded and updated version of the conference article published in the proceedings of the 2018 POMS International Conference in Rio (Clemente et al., 2020), whose proceedings title is "Operations Management for Social Good". This article is organized as follows. Section 1 brings the introduction. In section 2, the research methods are presented. Section 3 brings the main results and discussions while in section 4, the main conclusions are drawn.

\section{RESEARCH METHODS}

This article combines quantitative and qualitative approaches in its research design. Combining both approaches through bibliometrics and systematic literature review enhances research strength due to the complementarity of both methods (Carvalho et al. 2013). Quantitative techniques encompassed bibliometric analysis, aiming to identify the main citations patterns and fields of research in the intersection between business models and modularity. VosViewer software was used to generate keywords, co-citation and country co-authorship networks (van Eck and Waltman, 2010). As for qualitative techniques, content anal- 
ysis was developed in order to identify and elaborate on the themes and patterns found in the sample articles (Hsieh and Shannon, 2005; Elo and Kyngäs, 2008).

The sampling process was carried out in ISI Web of Science Core Collection and Scopus, and it was executed in June 2018, since these databases provided complete metadata for bibliometric analysis (Carvalho et al. 2013). The keywords for this research were "business model*" AND "modular*", selected as "topic" in ISI Web of Science and as "article title, abstract and keyword" in Scopus. In this initial research, only "type of document" was used as "articles"; "reviews" and "articles in press" were selected to compose the final sample. In ISI Web of Science Core Collection, 119 articles were found in total, while the totality of 202 articles was identified in Scopus. Once the abovementioned filters were applied, the sample contained 59 articles in ISI Web of Science and 84 articles in Scopus. By comparing these documents in both databases, 42 articles were overlapping (articles found in both databases). The final sample was then extracted from ISI Web of Science. On the other hand, it was later checked whether 42 articles that were only found in Scopus were also located in the ISI Web of Science Core Collection. In total, four out of 42 articles that were only in Scopus were also found in ISI Web of Science but did not appear in the first research in this database. Consequently, they were included in the final ISI Web of Science Core Collection database, resulting in a sample of 63 articles for analysis.

\section{RESULTS AND DISCUSSION}

In the final sample extracted from the ISI Web of Science Core Collection, the 63 articles had 698 citations combined, comprising an average of 11.08 citations per article. Moreover, the h-index of this sample was 13. Sherwood (1996) developed the first article published on this theme. His research described a method for enterprise security architecture and strategy. The yearly evolution of publications is presented in Table 1 as it shows an inconsistent number of published articles throughout the years. The period 20142018 contained $52,38 \%$ of the total articles in the sample while the year 2017 itself contained the highest number of publications, totalling 13 articles. Consequently, it sheds light on the growing interest on business model and modularity in recent years.

In regards to publishing outlets, articles on business model and modularity were published sparsely as 58 journals were identified. Therefore, there was no concentration of publications in a few journals as only five journals had two publications each, while the remaining articles were pulverized in 53 journals publishing one article each. The five journals that published two articles each were: (i) Chembioeng Reviews, (ii) Chemie Ingeniuer Technik, (iii) International
Journal of Operations \& Production Management, (iv) International Journal of Technology Management, and (v) Journal of Cleaner Production.

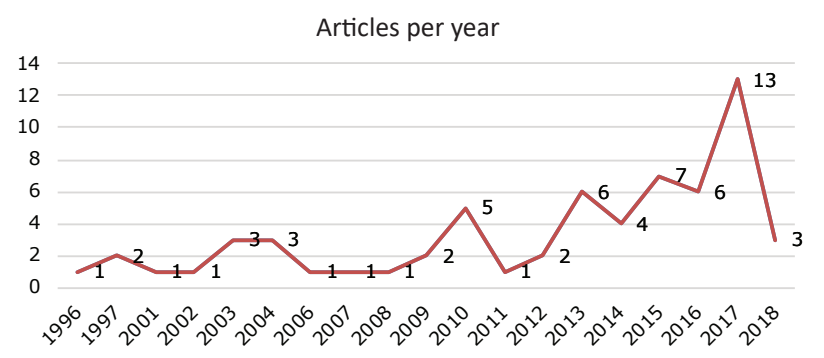

Figure 1. Number of articles per year

Source: Extracted from ISI Web of Science Core Collection (2018)

Calculating the Adjusted Impact Factor (AIF) allows the identification of the most relevant articles within a sample, based on the average yearly citation and Journal Impact Factor (JCR)(Carvalho et al., 2013). The Adjusted Article Impact Factor (AIF) was calculated for this sample and it was based on Equation 1, as follows (Carvalho et al., 2013):

$$
\text { AlF = Average yearly citation } *(1+J C R)(\text { Equation } 1)
$$

Considering the yearly average citation into this calculation, it reduces considerable weight on older articles as they tend to have more citations than newer ones (Homrich et al., 2017). Citation means the number of times an article is mentioned/cited by other articles in a database (Clemente et al., 2018). Table 1 shows the twenty articles with the highest Adjusted Impact Factors (AIF):

Spring and Araujo (2009) had both the highest total citation and average yearly citation both in the sample and in the Adjusted Article Impact Factor (Aif) calculation; it remained as the article with the highest factor. In addition, the articles of Richter (2013), Meier et al. (2011), Christensen et al. (2002) and Hessel et al. (2013)Acoustic and Plasma assisted SYNtheses composed the remaining articles in the top five articles with the highest average yearly citation. Similarly, by taking the Adjusted Impact Factor (AIF) into consideration, Richter (2013) remained in the second place, while Meier et al. (2011), for example, went down from the $3^{\text {rd }}$ to the $5^{\text {th }}$ position, Christensen et al. (2002) moved down from $4^{\text {th }}$ to $6^{\text {th }}$ position and Hessel et al. (2013) moved down from $5^{\text {th }}$ to $7^{\text {th }}$ position. In contrast, the article of Handel et al. (2014) went up from $6^{\text {th }}$ to $3^{\text {rd }}$ position and Tsvetkova and Gustafsson (2012) moved up from the $8^{\text {th }}$ place to the $4^{\text {th }}$.

In figure 2, the keywords network is shown, aiming to demonstrate the relationship pattern of keywords, indicating the themes that are being discussed by the articles in 
Table 1. List of the ten highest Article Impact Factors (Aif)

\begin{tabular}{|c|c|c|c|c|c|}
\hline Article & Journal & $\begin{array}{c}\text { JCR } \\
(2017)\end{array}$ & $\begin{array}{c}\text { Total } \\
\text { Citation }\end{array}$ & $\begin{array}{c}\text { Average } \\
\text { Yearly } \\
\text { Citation }\end{array}$ & AIF \\
\hline Spring and Araujo (2009) & $\begin{array}{l}\text { International Journal of Operations \& } \\
\text { Production Management }\end{array}$ & 2,955 & 123 & 12,3 & 48,65 \\
\hline Richter (2013) & Renewable Energy & 4,900 & 41 & 6,83 & 40,30 \\
\hline Handel et al. (2014) & leee Systems Journal & 4,337 & 26 & 5,2 & 27,75 \\
\hline Tsvetkova and Gustafsson (2012) & Journal of Cleaner Production & 5,651 & 27 & 3,86 & 25,67 \\
\hline Meier et al. (2010) & $\begin{array}{l}\text { International Journal of Advanced } \\
\text { Manufacturing Technology }\end{array}$ & 2,601 & 52 & 6,5 & 23,41 \\
\hline Christensen et al. (2002) & Industrial and Corporate Change & 2,198 & 110 & 6,47 & 20,69 \\
\hline Hessel et al. (2013) & Chemical Engineering and Processing & 2,826 & 32 & 5,33 & 20,39 \\
\hline Leurent et al. (2017) & Energy Policy & 4,039 & 6 & 3 & 15,12 \\
\hline Cenamor et al (2017) & $\begin{array}{c}\text { International Journal of Production } \\
\text { Economics }\end{array}$ & 4,407 & 5 & 2,5 & 13,52 \\
\hline Ray and Ray (2010) & $\begin{array}{c}\text { leee Transactions on Engineering } \\
\text { Management }\end{array}$ & 1,416 & 42 & 4,67 & 11,28 \\
\hline Storbacka and Nenonen (2009) & $\begin{array}{l}\text { Journal of Business \& Industrial Mar- } \\
\text { keting }\end{array}$ & 1,833 & 37 & 3,7 & 10,4821 \\
\hline Müller-Seitz and Reger (2010) & Technovation & 4,802 & 14 & 1,56 & 9,05112 \\
\hline Bonarini et al. (2014) & Robotics and Autonomous Systems & 2,638 & 12 & 2,4 & 8,7312 \\
\hline Snihur and Tarzijan (2018) & Long Range Planning & 3,221 & 2 & 2 & 8,442 \\
\hline Tsvetkova et al. (2015) & Journal of Cleaner Production & 5,651 & 4 & 1 & 6,651 \\
\hline Stafford and Blignaut (2017) & Ecosystem Services & 4,395 & 2 & 1 & 5,395 \\
\hline Hellström (2014) & Journal of Service Management & 3,414 & 6 & 1,2 & 5,2968 \\
\hline Kodama (2004) & $\begin{array}{c}\text { Technological Forecasting and Social } \\
\text { Change }\end{array}$ & 3,129 & 19 & 1,27 & 5,24383 \\
\hline Liu et al. (2017) & Journal of Management in Engineering & 2,282 & 3 & 1,5 & 4,923 \\
\hline Lier et al. (2016) & Chemie Ingenieur Technik & 1,100 & 8 & 2 & 4,2 \\
\hline
\end{tabular}

Source: authors

the sample. Similarly, the clusters in this network identify the association of keywords and themes within the business model and modularity that are being discussed in a closer manner. In this sense, all seven clusters are discussed and analysed.

The green cluster sheds light on modularity and its discussion of products and product architectures as one form of managing complexity in this domain (Schilling, 2000; Mikkola and Gassmann, 2003; Ethiraj and Levinthal, 2004) and, consequently, its possible rolling out effect to modularity in supply chains and networks. The purple cluster discusses business models, with capabilities and value creation being two important building blocks, as well as its role in enhancing ways of competitive advantage, considering business models as boundary-spanning activities as the way a firm communicates with external stakeholders (Zott and Amit, 2007). The yellow cluster links services and product architecture to mass-customization as mass-customization in services is difficult to achieve (Bask et al., 2011a; Carlborg and Kindström, 2014); therefore, modularity is one way to achieve customization and fulfil heterogeneity of demands in services (Bask et al., 2011a). Similarly, modularity applied to product architecture enables mass customization as an important outcome (Mikkola, 2007).

In the light blue cluster, keywords such as innovation, platform, and customization are linked. These keywords refer to the use of modularity-enabled platforms for innovation, whether in services (Eloranta and Turunen, 2016) or products (Muffatto and Roveda, 2002; Facin et al., 2016) as well as for customization (Mikkola, 2007; Pekkarinen and Ulkuniemi, 2008; Eloranta and Turunen, 2016; Facin et al., 2016). On the other hand, the red cluster brings keywords such as modular logistics, modular plants, modular production, and modularization. These combinations of keywords indicated that modularization is also applied to systems that go beyond the traditional domain of product architecture, 
also encompassing production system and logistics (Campagnolo and Camuffo, 2010). The dark blue cluster brings keywords such as markets, strategies, and competition along with architectural innovation as another observed keyword. This association of key words shed light on the importance of new technologies that create and shape new markets with new dominant concepts (Abernathy and Clark, 1985; Henderson and Clark, 1990) and the strong competition in the earlier stages around components and their linkages (Henderson and Clark, 1990), because architectural innovation is generally initiated by changes in components, thus requiring strategies for managing architectural knowledge (Henderson and Clark, 1990).

Co-citation network is shown in Figure 3. This is the most relevant network as it aims to identify the theoretical pillars of the articles in a sample (Carvalho et al., 2013; Homrich et al., 2017). Considering a minimum of 32 citations per document, this network is composed of three clusters.

Firstly, the blue cluster brings the organizational aspects of modularity to the forefront of the discussion. Garud and Kumaraswamy (1995) highlight that the design of a technological system for realized substitution economies has to be accompanied by the design of organizational systems that could foster this economy of substitution. In this sense, this organizational system must allow for modular upgradability, in which the elements - organizational modules - in this system can work independently (Garud and Kumaraswamy, 1995). Langlois and Robertson (1992) discuss how modular systems can be enhanced through centralized and decentralized networks of firms. In this sense, the authors highlight that in a centralized network, the members of the network are tied to the leading firm (Langlois and Robertson, 1992) while in a decentralized network, there are no leading firms dictating or controlling the common standards (Langlois and Robertson, 1992). In the work of Schilling and Steensma (2001), modularity principles are drawn in order to explain modular organizational forms in some industries. Schilling and Steensma (2001) point out that heterogeneity of inputs and demands, availability of standards, competitive intensity, and technological change are drivers for industries to pursue modular organizational forms - and its associated benefit of flexibility - such as alliances, contract manufacturing, and alternative work arrangements. The remaining two articles in this cluster discuss business models as boundary-spanning organizational design (Zott and Amit, 2007) and the fit between product market strategy and business model for company performance (Zott and Amit, 2008). Zott and Amit (2007) relate the business model and its impact to firm's performance, considering two types of business models: novelty-centered and efficiency-centered business models. Zott and Amit (2007) explain that novelty-centered business models are related to new forms of conducting exchanges with external stakeholders engaged by firms, while efficiency-centered business models are forms of achieving transaction efficiency through business models, having its core on the reduction of transaction costs. The authors conclude that novelty-centered are associated with higher performance levels. Similarly, Zott and Amit (2008) are based on the two abovementioned business model types (novelty-centered and efficiency-centered), thus examining the fit between business models and product market strategies (cost leadership, product differentiation and early market entry) to firm's performance. As a conclusion, Zott and Amit (2008) highlight that there is a positive interaction between novelty-centered business models and multiple product market strategies, such as cost leadership while, on the other hand, there were no support for the positive interaction between efficiency-centered business models and cost leadership strategy.

The green cluster overall discusses capabilities and business models. Eisenhardt and Martin (2000) discuss dynamic capabilities and, more broadly, resource-based view. In this discussion, Eisenhardt and Martin (2000) highlight that dy-

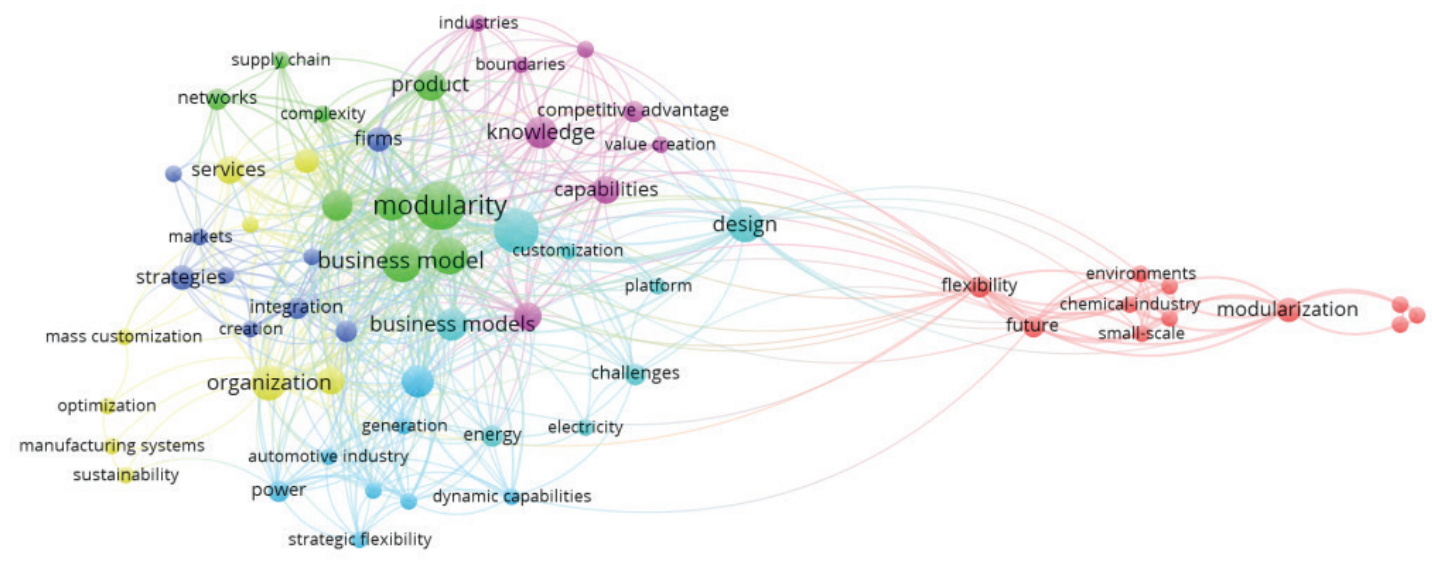

Figure 2. Keywords network considering a minimum of two citations 
namic capabilities have their strategic value in the manipulation of resources to value-creating strategies; therefore, competitive advantage is related to resources configuration and not dynamic capabilities. Chesbrough and Rosenbloom (2002) discuss business models as a mediating construct of the technical and economic domains, which shows how technologies can be selected and offered to markets in order to capture value. Casadesus-Masanell and Ricart (2010) propose a framework to distinguish the concepts of strategy, business model and tactics. Strategy is how a firm chooses a business model to compete, business models represents the logics of the firm and how it will operate in order to create value and tactics are the choices a firm has according to the business model it selected (Casadesus-Masanell and Ricart, 2010). Although the concepts of strategy and business models are related in a way that business models reflect an accomplished strategy, they are different concepts (Casadesus-Masanell and Ricart, 2010).

In the green cluster, Teece (2010) discusses business model in a theoretical manner, defining it as the architecture for value creation, delivery and capture. However, Teece (2010) highlights that research fields such as economics, strategy and organization and innovation have failed in giving the necessary importance to the business model concept and, therefore, are poorly understood. Demil and Lecocq (2010) draw from a Penrosian-based view in order to define a business model as a set of three important components - resources and components, organizational structure, and propositions for value delivery - that permanently interact and change over time in order to achieve equilibrium. In the work of Chesbrough (2010), the focus is on the barriers to business model innovation, which were identified as the conflicts between existing assets and business models as well as cognitive problems in understanding these barriers. Baden-Fuller and Morgan (2010) define the concept of business model as having a multivalent character, and it is considered as a description of kinds in taxonomy, in models and in recipes. In the first character, business models are generic descriptors - in an observed or abstract level - that demonstrate how firms create and deliver values, while in the model character, business models are depicted in the scientific sense in which they are considered as representatives of a class of things (Baden-Fuller and Morgan, 2010). As recipes, business models are composed of strategic elements and the way these elements are integrated and dealt together (Baden-Fuller and Morgan, 2010). Lastly in the green cluster, Zott et al. (2011) review the business model literature in order to identify three main concepts, such as (i) e-business model archetypes, (ii) business models as activity systems and (iii) business models as cost/revenue architecture. Moreover, Zott et al. (2011) highlight that four

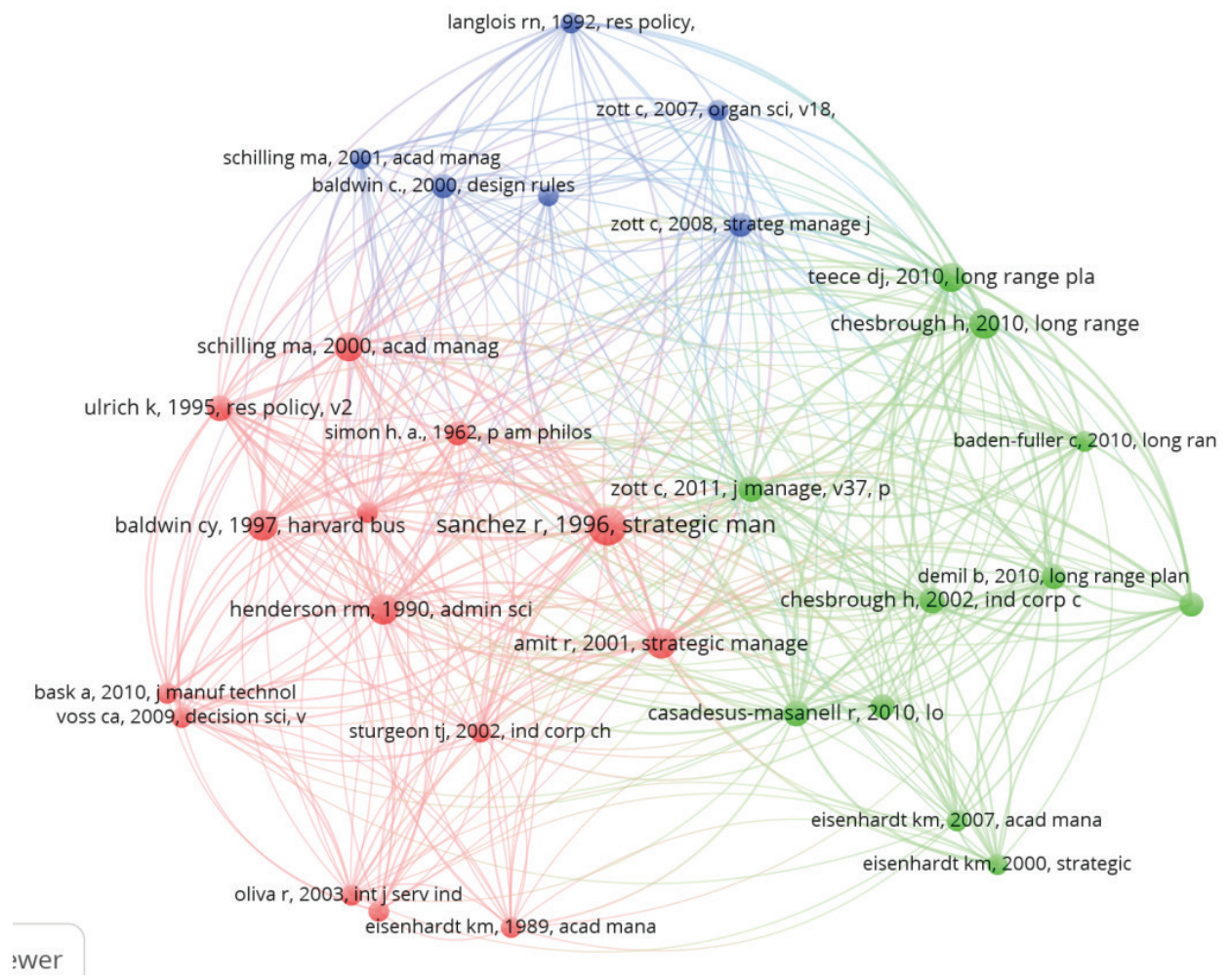

Figure 3. Co-citation network considering a minimum of 32 citations per document 
main themes are emerging around the business model concept. They are (i) business model as a new unit of analysis, (ii) business model as a systemic perspective in terms of how firms engage in doing business, (iii) business model as boundary-spanning activities, and (iv) business model as a way of value creation and not only as a way to capture value.

The red cluster discusses, overall, modularity that covers multiple topics. Henderson and Clark (1990) build a framework for defining innovation, covering incremental innovation, modular innovation, architectural innovation, and radical innovation. However, the interest of Henderson and Clark (1990) is on architectural innovation in which the components and design concepts remain unchanged, but the ways these components are linked are new. According to Henderson and Clark (1990), the effect of architectural innovation depends on the related concepts of component and architectural knowledge and, therefore, depends on the nature of the organizational knowledge. The theoretical conceptual nature of the work of Ulrich (1995) provides definitions for product architecture and their typologies. Ulrich (1995) defines product architecture as the scheme in which functions are allocated to physical components of a product through the (i) arrangement of functional elements, (ii) mapping of functional elements to physical components, and (iii) specification of interfaces among components. In addition, Ulrich (1995) highlights that architectures can range from integral to modular and, in modular architectures, they can be subdivided into (i) slot, (ii) bus, and (iii) sectional, all of which have implications for product change, product variety, component standardization, product performance, and product development management.

Also in the red cluster, Sturgeon (2002) discusses modular production networks based on the contract manufacturing experience of the American electronics industry. In this sense, Sturgeon (2002) defends that modular production networks yield better economic performance and are part of a process of industrial transformation. Voss and Hsuan (2009) designed from product architecture and modularity to develop a conceptualization of service architecture containing four levels, such as (i) industry, (ii) service company/ supply chain, (iii) service bundle, and (iv) service package/ component. In addition, Voss and Hsuan (2009) propose a service modularity function in order to measure the degree of modularity from unique services and the replicability of modules across services. The works of Bask et al. (2010b) and Campagnolo and Camuffo (2010) elaborated literature reviews for the concept of modularity. Bask et al. (2010b) argue that modularity has been used traditionally in product, production/manufacturing/processes, and organization/ supply chain. However, recent developments have focused on modularity of services (Bask et al., 2010b). Campagnolo and Camuffo (2010) review the concept of modularity in the management literature and have similar conclusions in terms of modularity being discussed around product, production systems and organizations. However, the authors highlight that the development of these three topics have received different degrees of attention, product modularity being the most developed while modularity in processes and organizations still lack significant theoretical and empirical developments (Campagnolo and Camuffo, 2010).

Lastly, in the red cluster, the work of Oliva and Kallenberg (2003) deal with the product-service continuum discussions as it elaborates on case studies about the transition from product to services in firms. According to Oliva and Kallenberg (2003), transitioning from products to services require new capabilities, managerial skills and organizational structures as well as business models' changes from transaction-based to relationship-based schemes. The article of Amit and Zott (2001), although not dealing with modularity compared to the other articles in this cluster, uncover four main factors for value creation in e-business: (i) efficiency, (ii) complementarities, (iii) lock-in, and (iv) novelty.

The country co-authorship in Figure 4 shows the collaboration between countries in regards to the intersection of business model and modularity. In total, four clusters were identified. The red cluster is composed of Denmark (2), Finland (7), France (2), and Sweden (5), with a total of 16 documents while the green cluster comprises Germany (14), Australia (4), and Greece (3), totalling 21 articles and, therefore, being the largest one in terms of articles. In addition, the blue cluster encompasses England (9), China (3), and United States (7), coming to 19 documents in total. Lastly, the yellow cluster, which is the smallest one in terms of countries and documents, is composed of Italy (5), and The Netherlands (3), totalling 8 documents.

\section{CONCLUSIONS}

The aim of this article was to analyse the intersection between the constructs of modularity and business model in the literature. In this way, this article contributes to the literature in two forms. In the first one, an overview of the literature is presented by evidencing the recent and increasing academic interest in this theme, especially in the period of 2014-2018 when the total number of publications totalled $52.38 \%$ of articles in the sample. In addition, the small sample of articles (63 articles collected from ISI Web of Science Core Collection) highlights that, even though the concepts of business model and modularity have been discussed for decades, their intersection is rather recent in the literature.

In the second form, this article demonstrated the key topics and trends. Traditionally, modularity has been utilized in three main domains; (i) product modularity, (ii) production modularity, and (iii) organizational modularity. On the other 


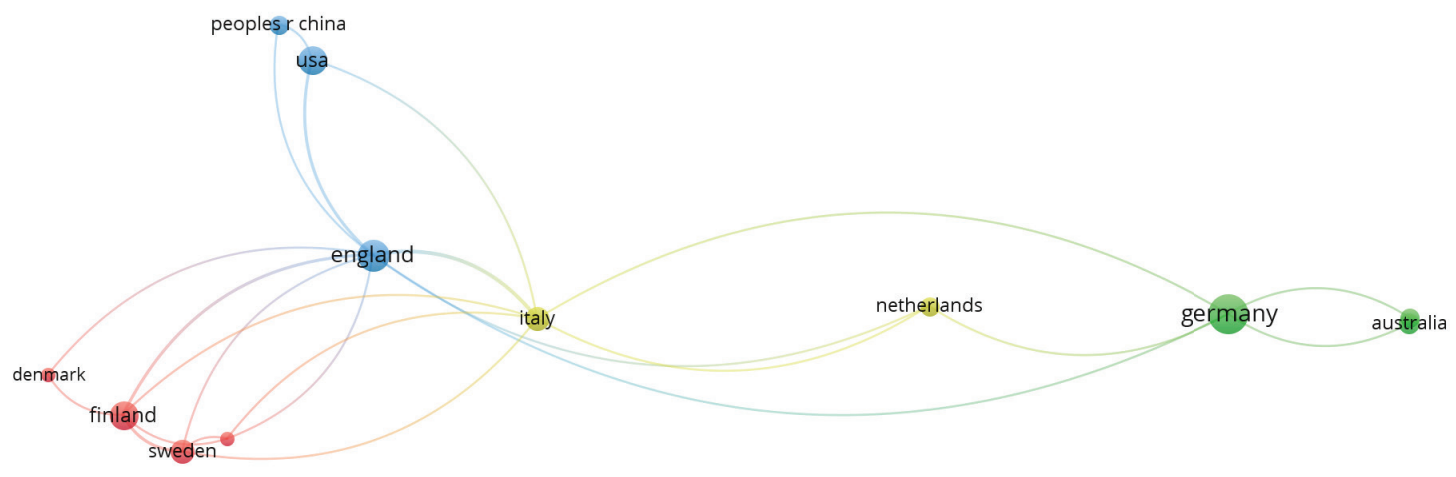

Figure 4. Country co-authorship considering a minimum of two documents per country Source: Authors

hand, research has recently applied the concept of modularity to the service domain and to business model, entailing modularization of business models. The co-citation network shows that several topics are being used as theoretical pillars of the articles in the sample. However, it clearly shows that these theoretical pillars also combine the discussions of modularity and business models.

Through this research, it was identified that modularity is a way of managing complexity and that business models and capabilities are important for value creation and competitive advantage. Moreover, through the co-citation network, the theoretical pillars utilized by the articles in the sample gravitate around three main clusters: (i) dynamic capabilities and the business model concept, (ii) modularity in topics covering architectures, networks and the current state of the modularity concept in the literature, and (iii) modularity based on an organizational perspective.

Lastly, future research should elaborate on the application of the concept of modularity in areas that go beyond the traditional domains of product, production and organizational modularity, such as services, business models and business model innovation. Also, future research should explore how the intersection of modularity and business model can impact firm performance both in manufacturing and services firms. The main limitation of this study lies in the sampling process as it comprised only ISI Web of Science Core Collection articles as other databases can be explored in future research. Moreover, the search strings utilized can also bring bias to the sampling process of this research.

\section{REFERENCES}

Abdelkafi, N. et al. (2018), "Business models of entrepreneurial universities in the area of vocational education - an exploratory analysis", International Journal of Technology Management, Vol. 77, No. 1/2/3, pp. 86-108. doi: 10.1504/ IJTM.2018.10012939.
Abernathy, W. J. and Clark, K. B. (1985), "Innovation : Mapping the Winds of Creative Destruction", Research Policy, Vol. 14, No. 1, pp. 3-22.

Amit, R. and Zott, C. (2001), "Value creation in E-business", Strategic Management Journal, Vol. 22, No. 6-7, pp. 493-520. doi: 10.1002/smj.187.

Amit, R. and Zott, C. (2015), "Crafting Business Architecture: the Antecedents of Business Model Design", Strategic Entrepreneurship Journal, Vol. 9, No. 4, pp. 331-350. doi: 10.1002/sej.1200.

Aversa, P. et al. (2015), "From Business Model to Business Modelling: Modularity and Manipulation", Business Models and Modelling, Vol. 33, pp. 151-185. doi: 10.1108/S0742332220150000033022.

Avlonitis, V. and Hsuan, J. (2017), "Exploring modularity in services: cases from tourism", International Journal of Operations \& Production Management, Vol. 37, No. 6, pp. 771-790. doi: 10.1108/IJOPM-08-2015-0531.

Baden-Fuller, C. and Morgan, M. S. (2010), "Business models as models", Long Range Planning, Vol. 43, No. 2-3, pp. 156-171. doi: 10.1016/j.Irp.2010.02.005.

Bask, A. H. et al. (2010a), "Matching service strategies, business models and modular business processes", Business Process Management Journal, Vol. 16, No. 1, pp. 153-180. doi: 10.1108/14637151011017994.

Bask, A. et al. (2010b), "The concept of modularity: Diffusion from manufacturing to service production", Journal of Manufacturing Technology Management, Vol. 21, No. 3, pp. 355-375. doi: 10.1108/17410381011024331.

Bask, A. et al. (2011a), "Framework for modularity and customization: service perspective", Journal of Business \& Industrial Marketing, Vol. 26, No. 5, pp. 306-319. doi: 10.1108/08858621111144370.

Bask, A. et al. (2011b), "Modularity in logistics services: a business model and process view", International Journal of Services and Operations Management, Vol. 10, No. 4, p. 379. doi: 10.1504/IJSOM.2011.043463. 
Bonarini, A. et al. (2014), "R2P: An open source hardware and software modular approach to robot prototyping", Robotics and Autonomous Systems, Vol. 62, No. 7, pp. 1073-1084. doi: 10.1016/j.robot.2013.08.009.

Boons, F. et al. (2013), "Sustainable innovation, business models and economic performance: an overview", Journal of Cleaner Production, Vol. 45, pp. 1-8. doi: 10.1016/j.jclepro.2012.08.013.

Bouncken, R. B. et al. (2016), "The role of entrepreneurial orientation and modularity for business model innovation in service companies", International Journal of Entrepreneurial Venturing, Vol. 8, No. 3, p. 237. doi: 10.1504/ IJEV.2016.078973.

Brax, S. A. et al. (2017), "Service modularity and architecture - an overview and research agenda", International Journal of Operations \& Production Management, Vol. 37, No. 6, pp. 686-702. doi: 10.1108/IJOPM-03-2017-0191.

Campagnolo, D. and Camuffo, A. (2010), "The concept of modularity in management studies: A literature review", International Journal of Management Reviews, Vol. 12, No. 3, pp. 259-283. doi: 10.1111/j.1468-2370.2009.00260.x.

Carlborg, P. and Kindström, D. (2014), "Service process modularization and modular strategies", Journal of Business \& Industrial Marketing, Vol. 29, No. 4, pp. 313-323. doi: 10.1108/ JBIM-08-2013-0170.

Carvalho, M. M. et al. (2013), "An overview of the literature on technology roadmapping (TRM): Contributions and trends", Technological Forecasting and Social Change, Vol. 80, No. 7, pp. 1418-1437. doi: 10.1016/j.techfore.2012.11.008.

Casadesus-Masanell, R. and Ricart, J. E. (2010), "From strategy to business models and onto tactics", Long Range Planning, Vol. 43, No. 2-3, pp. 195-215. doi: 10.1016/j. Irp.2010.01.004.

Cenamor, J. et al. (2017), "Adopting a platform approach in servitization: Leveraging the value of digitalization", International Journal of Production Economics, Vol. 192, Jan., pp. 54-65. doi: 10.1016/j.ijpe.2016.12.033.

Chesbrough, H. (2010), "Business model innovation: Opportunities and barriers", Long Range Planning, Vol. 43, No. 2-3, pp. 354-363. doi: 10.1016/j.Irp.2009.07.010.

Chesbrough, H. and Rosenbloom, R. S. (2002), "The role of the business model in capturing value from innovation: evidence from Xerox Corporation's technology spin-off companies", Industrial and Corporate Change, Vol. 11, No. 3, pp. 529-555. doi: 10.1093/icc/11.3.529.

Christensen, C. M. et al. (2002), "Disruption, disintegration and the dissipation of differentiability", Industrial and Corporate Change, Vol. 11, No. 5, pp. 955-993. doi: 10.1093/ icc/11.5.955.
Clemente, D. H. et al. (2018), "Product-Service Systems (PSS) and Public Policies: Lessons from the Literature", Procedia CIRP, Vol. 73, pp. 284-290. doi: 10.1016/j.procir.2018.03.325.

Clemente, D. H. et al. (2020) "Business Model Innovation and Modularity: Overview of the Literature", in in Leiras A. et al. (Eds.), Operations Management for Social Good, 2018 POMS International Conference in Rio, Springer Proceedings in Business and Economics Series, Springer International Publishing. In press.

Demil, B. and Lecocq, X. (2010), "Business model evolution: In search of dynamic consistency", Long Range Planning, Vol. 43, No. 2-3, pp. 227-246. doi: 10.1016/j.Irp.2010.02.004.

van Eck, N. J. and Waltman, L. (2010), "Software survey: VOSviewer, a computer program for bibliometric mapping", Scientometrics, Vol. 84, No. 2, pp. 523-538. doi: 10.1007/ s11192-009-0146-3.

Eisenhardt, K. M. and Martin, J. A. (2000), "Dynamic Capabilities: What Are They?", Strategic Management Journal, Vol. 21, pp. 1105-1121. doi: 10.1002/1097-0266(200010/11)21:10/11<1105::AID-SMJ133>3.0.CO;2-E.

Elo, S. and Kyngäs, H. (2008), "The qualitative content analysis process", Journal of Advanced Nursing, Vol. 62, No. 1, pp. 107-115. doi: 10.1111/j.1365-2648.2007.04569.x.

Eloranta, V. and Turunen, T. (2016), "Platforms in service-driven manufacturing: Leveraging complexity by connecting, sharing, and integrating", Industrial Marketing Management, Vol. 55, pp. 178-186. doi: 10.1016/j.indmarman.2015.10.003.

Ethiraj, S. K. and Levinthal, D. (2004), "Modularity and Innovation in Complex Systems", Management Science, Vol. 50, No. 2, pp. 159-173. doi: 10.1287/mnsc.1030.0145.

Facin, A. L. F. et al. (2016), "The Evolution of the Platform Concept: A Systematic Review", IEEE Transactions on Engineering Management, Vol. 63, No. 4, pp. 475-488. doi: 10.1109/ TEM.2016.2593604.

Foss, N. J. and Saebi, T. (2017a) "Business models and business model innovation: Between wicked and paradigmatic problems", Long Range Planning, Vol. 51, No. 1, pp. 9-21. doi: 10.1016/j.Irp.2017.07.006.

Foss, N. J. and Saebi, T. (2017b), "Fifteen Years of Research on Business Model Innovation", Journal of Management, Vol. 43, No. 1, pp. 200-227. doi: 10.1177/0149206316675927.

Frandsen, T. (2017), "Evolution of modularity literature: a 25-year bibliometric analysis", International Journal of Operations \& Production Management, Vol. 37, No. 6, pp. 703-747. doi: 10.1108/IJOPM-06-2015-0366.

Gärtner, C. and Schön, O. (2016), "Modularizing business models: between strategic flexibility and path dependence", 
Brazilian Journal of Operations \& Production Management

Volume 16, Número 3, 2019, pp. 387-397

DOI: 10.14488/BJOPM.2019.v16.n3.a3
Journal of Strategy and Management, Vol. 9, No. 1, pp. 39-57. doi: 10.1108/JSMA-12-2014-0096.

Garud, R. and Kumaraswamy, A. (1995), "Technological and organizational designs for realizing economies of substitution", Strategic Management Journal, Vol. 16, No. S1, pp. 93-109. doi: 10.1002/smj.4250160919.

Handel, P. et al. (2014), "Smartphone-Based Measurement Systems for Road Vehicle Traffic Monitoring and Usage-Based Insurance", IEEE Systems Journal, Vol. 8, No. 4, pp. 1238-1248. doi: 10.1109/JSYST.2013.2292721.

Hellström, M. (2014), "Solution business models based on functional modularity - the case of complex capital goods", Journal of Service Management, Vol. 25, No. 5, pp. 654-676. doi: 10.1108/JOSM-07-2013-0198.

Henderson, R. M. and Clark, K. B. (1990), “Architectural Innovation : The Reconfiguration of Existing Product Tech- nologies and the Failure of Established Firms", Administrative Science Quarterly, Vol. 35, No. 1, pp. 9-30.

Hessel, V. et al. (2013), "Industrial applications of plasma, microwave and ultrasound techniques: Nitrogen-fixation and hydrogenation reactions", Chemical Engineering and Processing: Process Intensification, Vol. 71, pp. 19-30. doi: 10.1016/j. cep.2013.02.002.

Homrich, A. S. et al. (2017), "The Circular Economy Umbrella: Trends and Gaps on Integrating Pathways", Journal of Cleaner Production, Vol. 75, pp. 525-543. doi: 10.1016/j.jclepro.2017.11.064.

Hsieh, H.-F. and Shannon, S. E. (2005), "Three Approaches to Qualitative Content Analysis", Qualitative Health Research, Vol. 15, No. 9, pp. 1277-1288. doi: 10.1177/1049732305276687.

Kodama, F. (2004), “Measuring emerging categories of innovation: Modularity and business model", Technological Forecasting and Social Change, Vol. 71, No. 6, pp. 623-633. doi: 10.1016/S0040-1625(03)00084-2.

Kuula, S. et al. (2018) "Cost-efficient co-creation of knowledge intensive business services", Service Business, Vol. 12, No. 4, pp. 779-808. doi: 10.1007/s11628-018-0380-y.

Langlois, R. N. and Robertson, P. L. (1992), “Networks and innovation in a modular system: Lessons from the microcomputer and stereo component industries", Research Policy, Vol. 21, No. 4, pp. 297-313. doi: 10.1016/0048-7333(92)90030-8.

Leurent, M. et al. (2017), "Driving forces and obstacles to nuclear cogeneration in Europe: Lessons learnt from Finland", Energy Policy, Vol. 107, pp. 138-150. doi: 10.1016/j.enpol.2017.04.025.

Lier, S. et al. (2016), "Transformable Production Concepts: Flexible, Mobile, Decentralized, Modular, Fast", ChemBioEng Reviews, Vol. 3, No. 1, pp. 16-25. doi: 10.1002/cben.201500027.

Liu, G. et al. (2017), "Business Model Innovation and Its Drivers in the Chinese Construction Industry during the Shift to Mo- dular Prefabrication", Journal of Management in Engineering, Vol. 33, No. 3. doi: 10.1061/(ASCE)ME.1943-5479.0000501.

Meier, H. et al. (2010), "Industrial Product-Service systems-IPS2", CIRP Annals - Manufacturing Technology, Vol. 59, No. 2, pp. 607-627. doi: 10.1016/j.cirp.2010.05.004.

Meier, H. et al. (2011), "Industrial Product-Service Systems (IPS2)", The International Journal of Advanced Manufacturing Technology, Vol. 52, No. 9-12, pp. 1175-1191. doi: 10.1007/ s00170-010-2764-6.

Mikkola, J. H. (2006), "Capturing the Degree of Modularity Embedded in Product Architectures", Journal of Product Innovation Management, Vol. 23, No. 2, pp. 128-146. doi: 10.1111/j.1540-5885.2006.00188.x.

Mikkola, J. H. (2007), “Management of Product Architecture Modularity for Mass Customization: Modeling and Theoretical Considerations", IEEE Transactions on Engineering Management, Vol.54, No. 1, pp. 57-69. doi: 10.1109/TEM.2006.889067.

Mikkola, J. H. and Gassmann, O. (2003), “Managing modularity of product architectures: Toward and integrated theory", Transactions on Engineering Management, Vol. 50, No. 2, pp. 1-15. doi: 10.1109/tem.2003.810826.

Minatogawa, V. L. F. et al. (2018), "Business model innovation influencing factors: an integrative literature review", Brazilian Journal of Operations \& Production Management, Vol. 15, No. 4, pp. 610-617. doi: 10.14488/BJOPM.2018.v15.n4.a14.

Muffatto, M. and Roveda, M. (2002), "Product architecture and platforms: a conceptual framework", International Journal of Technology Management, Vol. 24, No. 1. doi: 10.1504/ IJTM.2002.003040.

Müller-Seitz, G. and Reger, G. (2010), "Networking beyond the software code? an explorative examination of the development of an open source car project", Technovation, Vol. 30, No. 11-12, pp. 627-634. doi: 10.1016/j.technovation.2010.07.006.

Oliva, R. and Kallenberg, R. (2003), "Managing the transition from products to services", International Journal of Service Industry Management, Vol. 14, No. 2, pp. 160-172. doi: 10.1108/09564230310474138.

Pekkarinen, S. and Ulkuniemi, P. (2008), "Modularity in developing business services by platform approach", The International Journal of Logistics Management, Vol. 19, No. 1, pp. 84-103. doi: 10.1108/09574090810872613.

Ray, P. K. and Ray, S. (2010), "Resource-Constrained Innovation for Emerging Economies: The Case of the Indian Telecommunications Industry", IEEE Transactions on Engineering Management, Vol. 57, No. 1, pp. 144-156. doi: 10.1109/ TEM.2009.2033044.

Richter, M. (2013), "German utilities and distributed PV: How to overcome barriers to business model innovation", Renewable Energy, Vol. 55, pp. 456-466. doi: 10.1016/j.renene.2012.12.052. 
Salvador, F. et al. (2002), "Modularity, product variety, production volume, and component sourcing: Theorizing beyond generic prescriptions", Journal of Operations Management, Vol. 20, No. 5, pp. 549-575. doi: 10.1016/S0272-6963(02)00027-X.

Scannella, E. (2015), "What drives the disintegration of the loan origination value chain in the banking business", Business Process Management Journal, Vol. 21, No. 2, pp. 288-311. doi: 10.1108/BPMJ-02-2014-0017.

Schilling, M. A. (2000), "Toward a General Modular Systems Theory and Its Application to Interfirm Product Modularity", The Academy of Management Review, Vol. 25, No. 2, p. 312. doi: $10.2307 / 259016$.

Schilling, M. A. and Steensma, H. K. (2001), "The use of modular organizational forms: an industry-level analysis", Academy of Management Journal, Vol. 44, No. 6, pp. 1149-1168. doi: $10.2307 / 3069394$.

Sherwood, J. (1996), "SALSA: A method for developing the enterprise security architecture and strategy", Computers \& Security, Vol. 15, No. 5, p. 406. doi: 10.1016/0167-4048(96)82606$\mathrm{X}$.

Snihur, Y. and Tarzijan, J. (2018), "Managing complexity in a multi-business-model organization”, Long Range Planning, Vol. 51, No. 1, pp. 50-63. doi: 10.1016/j.Irp.2017.06.010.

Spring, M. and Araujo, L. (2009), "Service, services and products: rethinking operations strategy", International Journal of Operations \& Production Management, Vol. 29, No. 5, pp. 444-467. doi: 10.1108/01443570910953586.

Stafford, W. and Blignaut, J. (2017), "Reducing landscape restoration costs: Feasibility of generating electricity from invasive alien plant biomass on the Agulhas Plain, South Africa", Ecosystem Services, Vol. 27, Part B, pp. 224-231. doi: 10.1016/j. ecoser.2017.04.008.

Storbacka, K. and Nenonen, S. (2009), "Customer relationships and the heterogeneity of firm performance", Journal of Business \& Industrial Marketing, Vol. 24, No. 5/6, pp. 360-372. doi: 10.1108/08858620910966246.

Sturgeon, T. J. (2002), "Modular production networks: a new American model of industrial organization", Industrial and
Corporate Change, Vol. 11, No. 3, pp. 451-496. doi: 10.1093/ icc/11.3.451.

Teece, D. J. (2010), "Business models, business strategy and innovation", Long Range Planning, Vol. 43, No. 2-3, pp. 172194. doi: 10.1016/j.Irp.2009.07.003.

Tsvetkova, A. et al. (2015), "Replication of industrial ecosystems: the case of a sustainable biogas-for-traffic solution", Journal of Cleaner Production, Vol. 98, pp. 123-132. doi: 10.1016/j. jclepro.2014.08.089.

Tsvetkova, A. and Gustafsson, M. (2012), "Business models for industrial ecosystems: a modular approach", Journal of Cleaner Production, Vol. 29-30, pp. 246-254. doi: 10.1016/j. jclepro.2012.01.017.

Ulrich, K. (1995), "The role of product architecture in the manufacturing firm", Research Policy, Vol. 24, No. 3, pp. 419440. doi: 10.1016/0048-7333(94)00775-3.

Voss, C. A. and Hsuan, J. (2009), "Service Architecture and Modularity", Decision Sciences, Vol. 40, No. 3, pp. 541-569. doi: 10.1111/j.1540-5915.2009.00241.x.

Zott, C. and Amit, R. (2007), "Business Model Design and the Performance of Entrepreneurial Firms", Organization Science, Vol. 18, No. 2, pp. 181-199. doi: 10.1287/orsc.1060.0232.

Zott, C. and Amit, R. (2008) "The fit between product market strategy and business model: implications for firm performance", Strategic Management Journal, Vol. 29, No. 1, pp. 1-26. doi: $10.1002 / \mathrm{smj} .642$.

Zott, C. et al. (2011), "The Business Model: Recent Developments and Future Research", Journal of Management, Vol. 37, No. 4, pp. 1019-1042. doi: 10.1177/0149206311406265.

\section{Acknowledgements}

The authors would like to thank the National Council of Technological and Scientific Development (CNPq), the Coordination for the Improvement of Higher Education Personnel (CAPES), and the Foundation for Research Support of the State of São Paulo (FAPESP) for supporting this research.

Received: 01 Mar 2019

Approved: 19 Jul 2019

DOI: 10.14488/BJOPM.2019.v16.n3.a3

How to cite: Clemente, D. H.; Hsuan, J.; Carvalho, M. M. (2019), "The intersection between business model and modularity: an overview of the literature", Brazilian Journal of Operations \& Production Management, Vol. 16, No. 3, pp. 387-397, available from: https://bjopm.emnuvens.com.br/bjopm/article/view/809 (access year month day). 